\title{
Psikolojik Sözleşmenin İş Tatmini ve İşten Ayrılma Niyeti Üzerindeki Etkisi: Bir Kamu Üniversitesi Örneği
}

\section{The Effect of Psychologic Contract on Job Satisfaction and Intention to Leave: The Case of a Public University}

\author{
Kemaleddin Eryeşi1 $1^{\mathrm{a}, *}$, Yasin Taşpınar ${ }^{\mathrm{b}}$ \\ ${ }^{a}$ Dr. Öğr. Üyesi, Şırnak Üniversitesi, İktisadi ve İdari Bilimler Fakültesi, İşletme Bölümü, 73000, Şırnak/Türkiye. \\ ORCID: 0000-0002-4678-8249
}

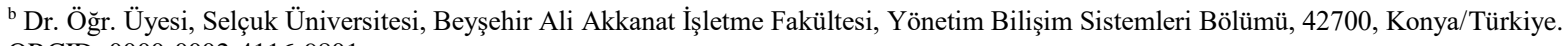
ORCID: 0000-0002-4116-9801

\section{MAKALE BİLGİSİ \\ Makale Geçmişi: \\ Başvuru tarihi: 31 Aralık 2020 \\ Düzeltme tarihi: 03 Nisan 2021 \\ Kabul tarihi: 10 Nisan 2021}

\section{Anahtar Kelimeler: \\ Psikolojik Sözleşme \\ İş Tatmini \\ İşten Ayrılma Niyeti \\ Akademik Personel}

\section{A R TICLE INFO}

Article history:

Received 31 December 2020

Received in revised form 03 April 2021

Accepted 10 April 2021

Keywords:
Psychological Contract
Job Satisfaction
Intention to Leave
Academic Staff

ÖZ

$\mathrm{Bu}$ araştırmanın amacı ilgili literatürden farklı olarak psikolojik sözleşme algısının, çalışanların iş tatminleri ve işten ayrılma niyetleri üzerindeki etkisini incelemektir. Bu bağlamda bir kamu üniversitesindeki 153 araştırma görevlisinin katıldığı bir alan araştırması yürütülmüştür. Verilerin analizinde SPSS (Sosyal Bilimler için İstatistik Paket Programı) programı kullanılmıştır. Analizler sonucunda araştırma görevlilerinin psikolojik sözleşme ve iş tatmini algıları ile işten ayrılma niyetleri üzerinde demografik faktörlerden eğitim ve akademik çalışma alanının etkili olduğu, söz konusu algı ve niyetler arasında ilişki bulunduğu ve psikolojik sözleşme algısının iş tatmini ve işten ayrılma niyeti üzerinde etkili olduğu tespit edilmiştir. Araştırma sonuçlarının yöneticiler ve kurumların çalışan tatminini artırarak işgücü devir hızını azaltmak amacıyla psikolojik sözleşme çerçevesini dikkate alması noktasında yol gösterici olması açısından kullanışlı olması beklenmektedir.

\section{A B S T R A C T}

The aim of this study aims to investigate the effect of psychological contract perception on employees' job satisfaction and their intention to leave distinctly from the related literature. In parallel with the context, the researchers have conducted a field study with the participation of 153 research assistants from a public university. SPSS (Statistical Package for Social Sciences) program is used for analysing the obtained data. The data shows that demographic factors of education and academic field of study are effective on the psychological contract perceptions and job satisfaction of the research assistants and their intention to leave. Furthermore, there is a relationship between the aforementioned perceptions and intentions. In the same way, the psychological contract perception is effective on job satisfaction and intention to leave. The findings of this research are significant in terms of guiding managers and institutions to consider the psychological contract framework to increase employee satisfaction and reduce the labour turnover rate.

\section{Introduction}

State universities are public institutions that employ civil servants working in-many academic positions and fields. Academic staff, who are associated with the civil service due to working in a public institution, have to keep up the pace with academic life while fulfilling the requirements of the civil service. Among the academicians within this scope,

\footnotetext{
* Sorumlu yazar/Corresponding author

e-posta: k.eryesil@sirnak.edu.tr
}

research assistants constitute the tenure of candidates, who will play a role in the future of academic life. Research assistants, who can be employed within the scope of the subclause "a" of $1^{\text {st }}$ clause of $33^{\text {rd }}$ article of the Higher Education Law numbered 2547 (tenured) or sub-clause "d" of $1^{\text {st }}$ clause of $50^{\text {th }}$ article of the same law (contracted), can have a permanent or scholarship status respectively in accordance with the aforementioned regulations. Although the 
employment type distinction at this point does not cause a significant change in the personal rights held during the tenure of research assistance, it makes a difference in the continuation or termination of the contract when the his or her graduate education finishes. In this context, academics working as research assistants might have a concern on continuation of the academic tenure. Taking this fact into consideration; the sample of is research assistants who have the scholarship (50/1d) status and work in a public university in Konya. The study will investigate the possible effect of psychological contract perception of the research assistants on their job satisfaction and resignation intentions.

In line with the managerial and technical developments, which determine today's business environment, it is-has seen that the psychological contract plays a significant role on employment relations of our times. The psychological contract is defined as a kind of cognition at the level of individuals. In terms of focusing on employee perceptions, it is possible to define psychological contract as "individual beliefs about the terms and conditions of a mutual agreement between the focal person and another party" or "individual beliefs on a mutual obligation between the individual and the organization" (Rousseau, 1989). The obligations consist of commitments, attitudes and intentions for future actions. The emphasis on the staffs' beliefs about what to be exchanged is an important feature of the psychological contract (Blomme, Van Rheede, \& Tromp, 2010: 146). The theoretical foundations of the psychological contract concept are based on the Social Exchange Theory of Blau (1989) (Van der Vaart, Linde, \& Cockeran, 2013: 358). According to the theory, the failure of an organization to fulfil its perceived obligations towards its employees results in a decrease in the employees' perceived obligation towards their organization, as well. It is stated that this situation will cause a decrease in job satisfaction, trust and employee commitment and an increase in the intention of leave the organization as well (Blau, 1989). Rousseau (1989) states that employees regard supervisor's explicit or perceived promises are the obligation of the organization. He (1989) also claims that any failure to fulfil those promises could be regarded as a breach of contract by the members of the organization. Those incidents also cause a tendency to create negative employee attitudes and behaviours (Behery, Abdallah, Parakandi, \& Kukunuru, 2016: 187).

In organizational behavioural literature, it is reported that failures to fulfil psychological contractual obligations are in a negative relation with job satisfaction (Robinson, \& Rousseau 1994; Johnson, \& O'Learry Kelly, 2003; Gakovic, \& Tetrick, 2003; Knights, \& Barbara, 2005; Zhao, Wayne, Glibkowski, \& Conway, 2007; Rigotti 2009; Bal, \& Dorien, 2011; Conway, Guest, \& Trenberth, 2011; Umar, \& Ringim, 2015) and positively associated with the intention to leave (Malik, \& Khalid, 2016; Turnley, \& Feldman, 2000; Conway, \& Briner, 2002; Turnley, Bolina, Lester, \& Bloodgood, 2003; Collins, 2010; Arshad, 2015; Zhao et al., 2007; Van der Vaart et al., 2013; Ballou, 2013; Behery et al., 2016). Intention to leave can be defined as the staff's subjective assessment of possibility of leaving the organization in a short time. The staff who want to leave the organization have strong negative behavioural reactions and attitudes that have detrimental effects on the morale of their colleagues and their performance as well (Van der Vaart et al., 2013: 358). Concordantly, the aim of our research is to determine the effect of research assistants' psychological contract perception on work/job satisfaction and intention to leave.

\section{Theoretical Framework}

Psychological contract perception is expected to have a positive effect on employees' performance and their satisfaction with the work/job of them, when they are pleased about the implementation of that contract. However, a displeasure on the issue mentioned causes them to think about leaving the organization. This section of the study involves the theoretical information on the concepts of psychological contract, job satisfaction and intention to leave.

\section{Psychological Contract}

This concept, defined as an implied "consensus" between a group of workers and their employers was first used by Argyris (1960). Later, Levinson (1962) defined the psychological contract concept as "the result of an unwritten agreement and mutual expectations of the employee from the job" (Manxhari, 2015: 232). The concept of psychological contract is structured on Blaus's (1989) Social Exchange Theory to conceptualize the employees' work relationship (Van der Vaart et al., 2013: 358). Social exchange theory consists the voluntary activities that emerge when employees are motivated by the returns they expect to receive as a result of the exchange (Aydın, 2017: 549). Social exchange is the motivation source to shape attitudes and behavioural responses of employees to psychological contracts. As the interactions of the various parties of job and working relationships progress over time, those parties act within the framework of rules agreed and relationships of exchange. As long as the parties of exchange feel indebted to the other ones, the relationship of exchange goes on and the parties become more willing to make sacrifices on behalf of others. However, when staff perceive that the balance of the psychological contract of them changes, the relationship of exchange between staff and the organization of them is changed, as well. Breach of psychological contract arises in case when employees realize that the organization of them is not delivering one/some of the promises they had given. That kind of breach of the psychological contract, which one of the basic concepts of social exchange theory, is defined as "cognitive evaluation in which a person notices that his/her organization cannot/do not fulfil its obligations" (Rayton, \& Yalabik, 2014: 2383).

No universally definition of the psychological contract is accepted (Manxhari, 2015: 233), however it is generally taken as the belief regarding the terms and conditions of the mutual exchange agreement between the employee and the employer. The belief of the employee is based on the perception about the contribution to employer he feels responsible for and the incentives that the employer believes his/her employer is obliged to give in return (Arshad, 2015: 252). Psychological contract is subjective in terms of its being dependent to the employee's view regarding the obligations that the organization must fulfil (Ballou, 2013: 2).

The psychological contract, which is the perception of the individual on his/her obligations towards the organization and to what extent the obligations of the organization are 
fulfilled (Blomme et al., 2010: 146), is divided into two components. Those are transactional and relational components. Transactional contracts involve exchange conditions for tangible monetary rewards that are short-term, are precise relatively and has a narrower scope. The essence of the transactional component may be explained as existence of a fair work and wage equation. In this case, the requirements of the job and expectations of the employees should be clearly pre-defined to assess costs and benefits before entering into the contract. On the other hand, relational agreements are structured on socio-emotional and non-monetary exchanges which are dynamic, and are not covering a specific time period, and are subject to the beliefs and perceptions of individuals. Relational contracts are based on less tangible rewards such as; trust, respect, and loyalty, which require considerable effort from the staff and their employers. For this reason, relational contracts are very crucial for companies, as they invest in improvement for their employees continuously in order to to boost up their employees' performance and loyalty (Behery et al., 2016: 186).

Psychological contracts are the source of non-compulsory behaviour, and they play a key role in terms of affecting employees' behaviours. Psychological contract is a kind of unwritten contract that assumes a social exchange relationship between staff and managers which brings obligations on a mutual trust (Kaya, 2013: 275). Failure to fulfil the psychological contract's aspects will ultimately cause a change in attitudes and behaviours therefore a violation of the contract. Rousseau (1989) suggests that violating the psychological contract can cause strong emotional responses such as anger, rage and feelings of injustice (Blomme et al., 2010: 146).

According to Rousseau (1995), the psychological contract is individual beliefs shaped by the organization in relation to an exchange agreement between individuals and their organizations. In employment relationships context, each party in that relationship has perceptions of the given promises and the accepted obligations. Organizations are sometimes incapable or unwilling to fulfil all obligations associated with the perceived mutual promises. That situation means the psychological contract breach (van der Vaart et al., 2013: 358). A study conducted by Robinson and Rousseau (1994) on behaviour, forward that the psychological contract breach leads to an employee turnover increase. Therefore, the concept of psychological contract provides a framework to investigate and interpret the employee's behaviour and attitudes such as job satisfaction and intention to leave (Blomme et al., 2010: 146). As a result of the violation of the psychological contract, employees begin to suffer from dissatisfaction with their work and, consequently show an increase in their tendency to to leave job.

\section{Job Satisfaction}

Job satisfaction, can be defined as the pleasure or positive emotional situation which is the result of one's evaluation of his/her job or experiences (Resnick, \& Bond, 2001: 12) is one of the major factors affecting job-related behaviours. Some of those behaviours are absenteeism, turnover etc. (Piko, 2006: 312). Furthermore, job satisfaction is a positive emotional situation arising from the evaluations of the employee of an organisation on the characteristics of the performed work. The level of satisfaction or that of dissatisfaction about the work is correlated with that positive emotion (Yücekaya, \& Gümüş, 2020: 46). It is possible to observe many factors, which has an effect on the level of job satisfaction (Yüksel, 2005: 306). However, it is possible to link job satisfaction to two main factors in general framework. The first factor is the personal characteristics of of the individual; which is related to individual's personality, feelings, thoughts, and desires. and his or her strengths over those needs. The second main factor which has an effect on the level of satisfaction is work conditions. It involves the physical and psychological conditions of work/job and compatibility of those conditions with the expectations of the individuals (Bayrak Kök, 2006: 293).

Another type of factor classification of job satisfaction is the two-factor theory of Herzberg, which is one of the most substantial issues of modern management approach (Çöp, \& Doğanay, 2020: 38). The two-factor theory was formulated by Herzberg and Mausner in 1959. They put forward that satisfaction and dissatisfaction are distinct two phenomena. The intrinsic factors of the work and nature of it such as responsibility or feeling of success are accepted as motivators. The extrinsic factors of the work such as payment, job security or management are seen dissatisfiers and called as hygiene factors (Lu, While, \& Barribal, 2005: 212; Örücü, Yumuşak, \& Bozkır, 2006: 42; Kahyaoğlu, \& Akca, 2020: 228). The satisfaction or dissatisfaction of the employee with his or her work/job is important for both the happiness of himself/herself and the productivity of the organization they work for. (Karcioğlu, \& Akbaş, 2010: 140; Kahya, 2013: 36; Sökmen, 2020: 2134). Additionally, due to its dynamic structure, organisations should give more importance to the factors affecting job satisfaction. In other words; when job satisfaction is achieved once, it should not be expected to be preserved without any measures taken for consolidating it (Yenihan, 2014: 174; Gümüş Dönmez, \& Topaloğlu, 2020: 312).

Studies on job-related attitudes have determined that nine job dimensions are effective on job satisfaction. Those factors are (Aşan, \& Erenler, 2008: 205-206):

$\checkmark$ Payment: This is not only related to the amount of payment itself, but also important in terms of comparing the employee's his or her own wage with other employees' wages.

$\checkmark$ Promotion: The opportunity of an employee to progress within the hierarchical structure of the organization.

$\checkmark$ Managers: Attitudes and behaviours of the managers towards the employees.

$\checkmark$ Additional Opportunities: The presence or absence of monetary and non-monetary opportunities of the organisation.

$\checkmark$ Possible Rewards: Recognition of the possibility of receiving an award for a good job behaviour.

$\checkmark$ Operational Procedures: The functioning of the business within the organization, the policies and procedures related to them.

$\checkmark$ Colleagues: Group members' technical and social competency and their support as well.

$\checkmark$ The Work Itself: The fact that whether the job or the related work fits with the interests of the employees. 
$\checkmark$ Communication: The desired level of communication with other individuals in the organization.

\section{Intention to Leave}

The breach of psychological contract is not to benefit of an organization in terms of its performance and productivity from the perspective of emotional consequence of employees' side. Employees dissatisfy with their works/jobs when they experience a psychological contract breach. This also causes a decrease in organizational commitment and ultimately increases intention to leave (Aykan, 2014). Employees' intention to leave is defined as the intention of an individual to leave the organization within a certain period. Their intention to leave stems from individuals negative views and attitudes towards their jobs and workplaces (Behery et al., 2016: 187). Intention to leave is a commonly used concept in the literature of organizational behaviour. (Price, 2001: 600). Organizations invest in recruitment, training and development of their employees; and give effort for the continuity of the organization. (Appollis, 2010: 34). For this reason, the determinants of the intention to leave have great importance not only for the employee -who is the subject of considering leaving the jobbut also for the manager who faces problems in terms of organizational efficiency and high costs resulting from the recruitment and training of new personnel (Van Schalkwyk, Du Toit, Bothma, \& Rothmann, 2010: 3).

The literature provides different definitions for intention to leave (Hemdi, \& Rahim, 2011: 78). Price (1989) defines the intention to leave as "current employees leaving the organization"; Vandenberg, \& Nelson (1999), as "the possibility of an individual to leave the institution permanently at some point in the near future"; Zhao et al. (2007), as "the tendency of an employee to leave the organization in a certain period in the future"; Lacity, Iyer, \& Rudramuniyaiah (2008), "the extent that an employee plans to leave the organization"; Takase (2010), as "willingness or attempt of employees to leave their current workplace voluntarily"; Matz, Woo, \& Kim (2014) as "conscious, deliberate willingness and determination to leave an organization".

The intention to leave is considered by an employer as an indicator of dissatisfaction with the person's employment. Principally, "intention to leave" is expressed as the intention of the staff to quit their job. Specifically, "intention to leave" refers to the subjective estimate of an individual's probability of leaving an organization in the near future (Cho, Johanson and Guchait, 2009: 375). The intention to leave is the consciousness and willingness of employees to quit the job. When employees experience psychological breach of contract; this can lead to an intention to leave the organization. If employees intend to resign but prefer to work for the organization due to other factors such as lack of job opportunities, they will be in constant disappointment because they do not respond fairly to their contributions (Malik, \& Khalid, 2016: 39).

Psychological contract perception is positively related with job satisfaction according to the literature (Robinson, \& Rousseau 1994; Johnson, \& O'Learry Kelly, 2003; Gakovic, \& Tetrick, 2003; Knights, \& Barbara, 2005; Zhao et al., 2007; Rigotti 2009; Bal, \& Dorien, 2011; Conway et al, 2011; Umar, \& Ringim, 2015). On the other hand, it is negatively correlated with intention to leave (Malik, \& Khalid, 2016; Turnley, \& Feldman, 2000; Conway, \& Briner, 2002; Turnley et al., 2003; Collins, 2010; Arshad, 2015; Zhao et al., 2007; Van der Vaart et al., 2013; Ballou, 2013; Behery et al., 2016). In the field study part of this research, we will test the mentioned relationships above to see if they are meaningful in the context of a public university. We will also analyse whether there is a significant difference among groups in terms of their perceptions of psychological contract, job satisfaction and intention to leave. Accordingly, the hypotheses of this research are:

Hypothesis 1: There are significant differences between the groups formed according to demographical characteristics of the participants in terms of their perceptions of psychological contract, job satisfaction, and intention to leave.

Hypothesis 2: Perception of psychological contract has a significant positive influence on job satisfaction.

Hypothesis 3: Perception of psychological contract has a significant negative influence on intention to leave.

\section{Method and Field Study}

The quantitative research method was used to determine whether the perception of psychological contract has an impact on job satisfaction and intention to leave. A questionnaire form was prepared including for this. It consists of 39 items. 6 of them are about demographic characteristics and 33 of them are about scale statements. 9 statements form the psychological contract scale, while 20 of them measure job satisfaction and 4 of them measure intention to leave. Psychological contract scale consists of the statements which are translated from the study of Robinson and Rousseau (1994). Job satisfaction scale is the short form of the questionnaire used by Weiss, Davis, \& England (1967) in their study. The third scale, which consists of the statements about intention to leave was adapted from the study of Rosin, \& Korabik (1995).

The questionnaire forms were distributed following the random sample method to the participants and collected between the dates of 20-25 November 2019. Although 170 questionnaires were distributed, 153 of them were completely and carefully filled out and included for the analysis process. The data obtained through the questionnaire forms was analysed by SPSS (Statistical Package for Social Sciences) program. Frequency analysis, ANOVA, $t$ test, Pearson correlation and Regression analysis were applied for the data. The results are given in the findings section of the study.

\section{Findings}

The first test used to analyse the data -which is derived through the quantitative field study is the reliability test, which is commonly used in the social sciences field research literature (Leech et al., 2005: 63). The results of the test are given below. 
Table 1: Reliability Analysis of The Scales

\begin{tabular}{lrc}
\hline Scale & $\begin{array}{c}\text { Number of } \\
\text { Items }\end{array}$ & $\begin{array}{c}\text { Cronbachs's } \\
\text { Alpha }\end{array}$ \\
\hline Psychological Contract & 9 & 0,882 \\
Job Satisfaction & 20 & 0,924 \\
$\quad$ Intrinsic & 12 & 0,874 \\
Extrinsic & 6 & 0,784 \\
Intention to Leave & 4 & 0,922 \\
\hline
\end{tabular}

The level of the alpha value determined shows the internal consistency of the used scale. While the alpha value gets closer to 1.00 , the probability of the scale to involve statements usable for measuring the same phenomenon. The common view about alpha coefficient about reliability of the scales is values above 0.70 is enough to define them reliable (Gaur, \& Gaur, 2009: 134). Accordingly, it can be stated that scales and sub-scales used in the quantitative field research are statistically reliable.

Frequency distributions give researchers the chance to determine which replies are given how many times by the participants (Pallant, 2007: 54). The table below has been prepared in order to show the demographical distribution of the participants.

Table 2: Demographic Characteristics of the Participants

\begin{tabular}{lcclrr}
\hline \multicolumn{1}{c}{ Age } & $\mathbf{N}$ & $\mathbf{\%}$ & Working Period & \multicolumn{1}{c}{$\mathbf{N}$} & \% \\
\hline $19-26$ & 37 & 24.18 & 1 year or less & 7 & 4.58 \\
$27-34$ & 83 & 54.25 & 1-5 years & 99 & 64.70 \\
$35-42$ & 20 & 13.07 & 6-9 years & 24 & 15.69 \\
43 and older & 13 & 8.50 & 10 y. or longer & 23 & 15.03 \\
\hline \multicolumn{1}{c}{ Gender } & $\mathbf{N}$ & $\mathbf{\%}$ & Marital Status & $\mathbf{N}$ & $\mathbf{\%}$ \\
\hline Female & 62 & 40.52 & Married & 81 & 52.94 \\
Male & 91 & 59.48 & Single & 72 & 47.06 \\
\hline Education & $\mathbf{N}$ & $\mathbf{\%}$ & Academic Field & $\mathbf{N}$ & $\mathbf{\%}$ \\
\hline Undergraduate & 36 & 23.53 & Life Sciences & 100 & 65.36 \\
Graduate & 117 & 76.47 & Social Sciences & 53 & 34.64 \\
\hline
\end{tabular}

As seen on the table, most of the research assistants, who accepted to participate this study are between the ages of 27 and 34 . The number of female participants is slightly less than male participants. A great majority of the research assistants have a graduate level of education, which is probably master's degree. Most of the participants have a tenure of 1 to 5 years and study in the field of life sciences. The percentage of married participants is almost the same level with the single participants.

In order to test the first hypothesis of this research, the data derived analysed by using $\mathrm{F}$ tests, which are used in order to compare the mean differences of the replies given to the statements of specific issues by one or more groups of participants (Page et al. 2003: 20). For the convenience of parametric tests such as ANOVA and T-Test the data has to be normally distributed. Otherwise, non-parametric alternatives of those tests (Kruskal-Wallis and MannWhitney U) should be preferred.

Table 3: Normality Distribution of the Scales

\begin{tabular}{|c|c|c|c|c|c|}
\hline Scale & Mean & Std Dev. & S./K. & Std Dev. & \\
\hline \multirow{2}{*}{$\begin{array}{l}\text { Psych. } \\
\text { Contract }\end{array}$} & \multirow{2}{*}{3,7545} & \multirow{2}{*}{0,04167} & Skewness & $-0,973$ & 0,196 \\
\hline & & & Kurthosis & $+1,994$ & 0,390 \\
\hline \multirow{4}{*}{$\begin{array}{l}\text { Job } \\
\text { Satisf. } \\
\text { Int. to } \\
\text { Leave }\end{array}$} & \multirow{2}{*}{3,8124} & \multirow{2}{*}{0,03729} & Skewness & $-1,984$ & 0,196 \\
\hline & & & Kurthosis & $+1,267$ & 0,390 \\
\hline & \multirow{2}{*}{1,8660} & \multirow{2}{*}{0,07198} & Skewness & $+1,373$ & 0,196 \\
\hline & & & Kurthosis & $+1,853$ & 0,390 \\
\hline
\end{tabular}

The skewness-kurthosis values of the scales of psychological contract, job satisfaction and intention to leave are -
0,973/1,994, -1,984/1,267 and 1,373/1,853 respectively, their standard deviations are $0,196 / 0,390$. The results show that the data is not normally distributed. On the other hand, it is only possible to discuss a mean difference, in case of its significancy. Thus, non-parametric tests will be used for testing the null hypothesis. In addition, because KruskalWallis test and Mann-Whitney U test do not show the mean values of the data according to groups, post hoc tests and explore menu will be deployed to determine them. The results of the Kruskal Wallis tests conducted to investigate whether there is a significant relationship between the demographical characteristics of the participants, taking age and working period into consideration. The results are given below.

Table 4: Differences between Age Groups and Working Period in Terms of Their Perceptions

\begin{tabular}{|c|c|c|c|}
\hline AGE GROUPS & Chi-Square & df & Asymp Sig \\
\hline Psychological Contract & 4,902 & 3 & 0,179 \\
\hline Job Satisfaction & 6,730 & 3 & 0,081 \\
\hline Intention to Leave & 2,624 & 3 & 0,453 \\
\hline WORKING PERIOD GROUPS & Chi- Square & df & Asymp Sig \\
\hline Psychological Contract & 1,644 & 3 & 0,649 \\
\hline Job Satisfaction & 0,952 & 3 & 0,813 \\
\hline Intention to Leave & 3,715 & 3 & 0,294 \\
\hline
\end{tabular}

For the scales of psychological contract, job satisfaction and intention to leave; the results indicate that there isn't any statistically difference between psychological contract perceptions, job satisfactions and intentions to leave in terms of the participant groups formed according to their age and period $(\mathrm{p}>0,05)$.

Since the Kruskal-Wallis test cannot be used when the number of the participant groups is limited with two; $t$ test which do not only test the null hypothesis, but also give the differences between the mean values of the group perceptions (Hinton et al. 2004: 106-107) is suggested. The second analysis to test the first hypothesis is the independent samples Mann-Whitney U test.; which check whether there are significant differences between marital status, education and academic field groups of the participants, in terms of their psychological contract perceptions, job satisfactions and intentions to leave.

Table 5: Differences between Groups in Terms of Their Perceptions

\begin{tabular}{|c|c|c|c|c|}
\hline GENDER & $\begin{array}{c}\text { Mann- } \\
\text { Whitney U }\end{array}$ & $\begin{array}{c}\text { Wilcoxon } \\
\text { W }\end{array}$ & $\begin{array}{l}\text { Sig (2- } \\
\text { tailed) }\end{array}$ & $\begin{array}{l}\text { Mean } \\
\text { Rank }\end{array}$ \\
\hline $\begin{array}{l}\text { Psychological } \\
\text { Contract }\end{array}$ & 2484,000 & 4254,000 & 0,430 & $\begin{array}{l}72,10 \\
77,10\end{array}$ \\
\hline Job Satisfaction & 2670,500 & 4440,500 & 0,956 & $\begin{array}{l}75,26 \\
75,65\end{array}$ \\
\hline $\begin{array}{l}\text { Intention to } \\
\text { Leave }\end{array}$ & 2563,000 & 6749,000 & 0,631 & $\begin{array}{l}77,56 \\
74,16 \\
\end{array}$ \\
\hline $\begin{array}{l}\text { MARITAL } \\
\text { STATUS } \\
\end{array}$ & $\begin{array}{c}\text { Mann- } \\
\text { Whitney U }\end{array}$ & $\begin{array}{c}\text { Wilcoxon } \\
\text { W } \\
\end{array}$ & $\begin{array}{l}\text { Sig }(2- \\
\text { tailed })\end{array}$ & $\begin{array}{l}\text { Mean } \\
\text { Rank }\end{array}$ \\
\hline $\begin{array}{l}\text { Psychological } \\
\text { Contract }\end{array}$ & 2479,500 & 5035,500 & 0,211 & $\begin{array}{l}79,61 \\
70,92\end{array}$ \\
\hline Job Satisfaction & 2503,500 & 5059,500 & 0,245 & $\begin{array}{l}79,31 \\
71,26\end{array}$ \\
\hline $\begin{array}{l}\text { Intention to } \\
\text { Leave }\end{array}$ & 2724,000 & 5884,000 & 0,755 & $\begin{array}{l}74,48 \\
76,63\end{array}$ \\
\hline EDUCATION & $\begin{array}{c}\text { Mann- } \\
\text { Whitney U }\end{array}$ & $\begin{array}{c}\text { Wilcoxon } \\
\text { W }\end{array}$ & $\begin{array}{l}\text { Sig (2- } \\
\text { tailed) }\end{array}$ & $\begin{array}{l}\text { Mean } \\
\text { Rank }\end{array}$ \\
\hline $\begin{array}{l}\text { Psychological } \\
\text { Contract }\end{array}$ & 1405,000 & 8075,000 & 0,011 & $\begin{array}{l}91,18 \\
70,00\end{array}$ \\
\hline Job Satisfaction & 1829,500 & 8499,500 & 0,561 & $\begin{array}{l}78,69 \\
73,91\end{array}$ \\
\hline
\end{tabular}




\begin{tabular}{|c|c|c|c|c|}
\hline $\begin{array}{l}\text { Intention to } \\
\text { Leave }\end{array}$ & 1473,000 & 2068,000 & 0,025 & $\begin{array}{l}60,82 \\
79,19 \\
\end{array}$ \\
\hline $\begin{array}{c}\text { ACADEMIC } \\
\text { FIELD }\end{array}$ & $\begin{array}{c}\text { Mann- } \\
\text { Whitney U }\end{array}$ & $\begin{array}{c}\text { Wilcoxon } \\
\text { W }\end{array}$ & $\begin{array}{l}\text { Sig (2- } \\
\text { tailed) }\end{array}$ & $\begin{array}{l}\text { Mean } \\
\text { Rank }\end{array}$ \\
\hline $\begin{array}{l}\text { Psychological } \\
\text { Contract }\end{array}$ & 295,500 & 1570,500 & 0,000 & $\begin{array}{l}97,54 \\
31,41\end{array}$ \\
\hline Job Satisfaction & 1053,000 & 2328,000 & 0,000 & $\begin{array}{l}89,97 \\
46,56\end{array}$ \\
\hline $\begin{array}{l}\text { Intention to } \\
\text { Leave }\end{array}$ & 970,500 & 6020,500 & 0,000 & $\begin{array}{r}60,20 \\
106,09\end{array}$ \\
\hline
\end{tabular}

The psychological contract perceptions, job satisfactions and intentions to leave of the participants do not significantly differ in terms of their gender and marital status. On the other hand; there is a significant difference between educational level groups when their psychological contract perception and intention to leave is considered. Psychological contract perception of research assistants -with a background of graduate education level- is more positive but the intention to leave is higher than the research assistants with background of undergraduate level education. The academic field groups exhibit significant differences in the context of all scales. In other words, their perceptions of psychological contract, job satisfaction and intention to leave are significantly different. The positive perceptions of the participants studying in the field of life sciences are higher, in terms of psychological contract and job satisfaction. On the other hand, their intention to leave is lower than that of the participants from social sciences area.

The responses given by the participants are analysed with correlation tests to check whether there are significant linear relationships between the answers given to the specified statements or the averages on the basis of expression groups. In order to make a determination that two variables are effective with each other, the linear relationship assumed between those two variables is needed to be meaningful. The value that is going to be checked for this is a 2-tailed significance value. The values below 0.05 indicate a $95 \%$ confidence interval, and values below 0.01 indicate a $99 \%$ confidence interval. The strength of the relationship between variables can be observed by looking at the $r$ value of the correlation. In the Spearman Correlation, which will be used as a means to analyse the relationship between variables in the study, the value closer to the \pm 1.00 , stronger the relationship between the variables. The evaluation for the table is showed below.

Table 6: Correlations between Psychological Contract, Job $\underline{\text { Satisfaction and Intention to Leave }}$

\begin{tabular}{clcc}
\hline & & $\begin{array}{c}\text { Job } \\
\text { Satisfaction }\end{array}$ & $\begin{array}{c}\text { Intention } \\
\text { to Leave }\end{array}$ \\
\hline Psychological & Corr. Coeff. & $0.6099^{\prime}$ & $-0.3711^{\prime}$ \\
Contract & Sig. (2-tailed) & 0.000 & 0.000 \\
\cline { 2 - 2 } Job & Corr. Coeff. & & $-0.255^{\prime}$ \\
Satisfaction & Sig. (2-tailed) & & 0,002 \\
\hline **. Correlation is significant at the 0.01 level (2-tailed). & \\
\hline
\end{tabular}

According to the table above; psychological contract perception has significant and strong relationship with job satisfaction and a mid-level relationship intention to leave. However, the relationship with job satisfaction is positive, while it is negative with intention to leave. Additionally, there is a significant but weak negative relationship between job satisfaction and intention to leave.

Due to the fact that the data does not have normal distribution; regression analysis using bootsrap (2000 bootsraps) for coefficients (Efron, \& Tibshirani, 1993: 81) will be drew on to test the second and third hypotheses. In other words, it will test whether the psychological contract perception of the participants has an effect on of their job satisfactions and intentions to leave. The results of the bootstrapping multiple regression analyses are given in tables 6 and 7 below.

Table 7: Effect of Psychological Contract on Job Satisfaction

\begin{tabular}{|c|c|c|c|c|c|c|c|}
\hline \multirow{3}{*}{$\begin{array}{l}\text { Dep. } \\
\text { Var. }\end{array}$} & \multirow{3}{*}{$\begin{array}{l}\text { Indep. } \\
\text { Var. }\end{array}$} & \multirow{3}{*}{ B } & \multicolumn{5}{|c|}{ Bootstrap $^{a}$} \\
\hline & & & \multirow{2}{*}{ Bias } & \multirow{2}{*}{$\begin{array}{l}\text { Std. } \\
\text { Error }\end{array}$} & \multirow{2}{*}{$\begin{array}{l}\text { Sig (2- } \\
\text { tailed) }\end{array}$} & \multicolumn{2}{|c|}{ Interval } \\
\hline & & & & & & Lower & Upper \\
\hline \multirow{2}{*}{$\begin{array}{l}\text { Job } \\
\text { Sat. }\end{array}$} & Constant & 1.933 & 0.002 & 0.300 & 0.000 & 1.339 & 2.516 \\
\hline & $\begin{array}{l}\text { Psych. } \\
\text { Cont. }\end{array}$ & 0.500 & 0.000 & 0.075 & 0.000 & 0.335 & 0.650 \\
\hline
\end{tabular}

When the results of the regression analysis are examined, it is determined that the explanatory variable -which is psychological contract- predicted the dependent variable which is job satisfaction- positively and statistically significantly and 1 unit increase for psychological contract explained 0,50 unit increase in job satisfaction $(p<0.05)$. Taking the results of the analysis is into account, it has seen that psychological contract perception of the research assistants, who participated in the field study, affected positively participants' job satisfaction. This result showed that the participants' job satisfaction level is increased, while their positive perception on the psychological contract getting more positive.

Table 8: Effect of Psychological Contract on Intention to Leave

\begin{tabular}{|c|c|c|c|c|c|c|c|}
\hline \multirow{3}{*}{$\begin{array}{l}\text { Dep. } \\
\text { Var. }\end{array}$} & \multirow{3}{*}{ Indep. Var. } & \multirow{3}{*}{ B } & \multicolumn{5}{|c|}{ Bootstrap $^{a}$} \\
\hline & & & \multirow{2}{*}{ Bias } & \multirow{2}{*}{$\begin{array}{l}\text { Std. } \\
\text { Error }\end{array}$} & \multirow{2}{*}{$\begin{array}{l}\text { Sig (2- } \\
\text { tailed) }\end{array}$} & \multicolumn{2}{|c|}{ Interval } \\
\hline & & & & & & Lower & Upper \\
\hline \multirow{2}{*}{$\begin{array}{l}\text { Int. to } \\
\text { Leave }\end{array}$} & Constant & 5.128 & 0.023 & 0.609 & 0.000 & 3.999 & 6.438 \\
\hline & $\begin{array}{l}\text { Psych. } \\
\text { Cont. }\end{array}$ & $-0,869$ & -0.006 & 0.155 & 0.000 & -1.207 & -0.585 \\
\hline
\end{tabular}

Observing the results of the regression analysis, it is possible claim that the explanatory variable, (psychological contract) is determined to predict the dependent variable (intention to leave) negatively and statistically significantly. Furthermore, 1 unit increase for psychological contract perception explain 0,87 unit decrease in intention to leave $(p<0.05)$. When the results of the analysis are evaluated, it is observed that psychological contract perception of the research assistants, who filled the questionnaire forms, affected their intention to leave in a negative way. In other words, their positive thoughts on the psychological contract which is between themselves and the organization they work for is valid. Therefore, it decreases their intention to leave the organization.

\section{Discussion}

The perceptions of the participants on psychological contract, job satisfaction and intention to leave do not differ significantly considering their working period and gender groups. The reason for this may be the equal working conditions of the research assistants is independent from their gender and working experience. However, those perceptions differ significantly, when the academic fields of the participants are taken into consideration. This result is 
interesting and it could be explained because the participants from life sciences area can find job more easily than those from social sciences area. The findings showed that the research assistants in life sciences area have better work conditions than the ones in social sciences. However, there are significant differences between age and marital status in terms of participants' perceptions of psychological contract; and between educational level groups in terms of their intention to leave. Those results indicate that the first hypothesis of this research is partially accepted.

The second hypothesis of this research is about a significant positive influence of psychological contract perception on job satisfaction. The results of the field study showed that the psychological contract perception of the participants has a significant, positive effect on job satisfaction and it predicts $31,9 \%$ of the cases. This result is compatible with the studies of Robinson, \& Rousseau (1994), Johnson, \& O'Learry Kelly (2003), Gakovic, \& Tetrick (2003), Knights, \& Barbara (2005), Zhao et al. (2007), Rigotti (2009), Bal, \& Dorien (2011), Conway et al. (2011) and Umar, \& Ringim (2015). In this context, the hypothesis is accepted.

Additionally, the third hypothesis about a significant negative influence of psychological contract perception on intention to leave is approved, as well. The results of this field study which is included research assistants working in a public university showed that the psychological contract perception of the participants has a significant, negative effect on job satisfaction and predicts $25,8 \%$ of the cases. This result is compatible with the studies of Malik, \& Khalid (2016), Turnley, \& Feldman (2000), Conway, \& Briner (2002), Turnley et al., (2003), Collins (2010), Arshad (2015), Zhao et al. (2007), Van der Vaart et al. (2013), Ballou (2013) and Behery et al. (2016).

\section{Conclusion}

Research assistants do not only work as a civil servant for public universities, but also do academic research in their areas. They become part of their organizations in one of the positions, which are the scholarship and permanent status positions. Although those types of positions do not cause a significant difference during their tenure, it creates difference for the decision of continuation or termination of their job contract once they finish their graduate education. The research assistants who participated in this study have the position of scholarship at a public university.

Both the private sector enterprises and some of the public institutions, and organisations such as universities have an issue of psychological contract which plays an important role on employee behaviours and attitudes. In organizational behaviour literature, implementing the framework of psychological contract is expected from the managers. A failure in that point lead to the employee take contract invalid and reconsider to be part of organization again. As a result of that perception; their dissatisfaction and the organization's turnover rate the organization is expected to increase.

This study aimed to explore whether the approach in the literature is valid or not through a field study in which the research assistants working in a public university accepted to participate in this research. The results given below are the ones derived from the analysis of the data obtained from a field study conducted in a public university in Konya;

$\checkmark$ The scales used in the study are reliable and consistent internally,

$\checkmark$ The difference of perceptions on psychological contract, job satisfaction and intention to leave of the groups formed according to age and period of work is not significant,

$\checkmark$ Psychological contract perception of research assistants who has a graduate-level education is more positive and intention to leave is higher than the research assistants with undergraduate-level education.

$\checkmark \quad$ The research assistants studying in the field of life sciences perceive psychological contract more positively and their job satisfaction is higher, while their intention to leave is lower than that of the participants from social sciences,

$\checkmark \quad$ There is a strongly positive significant relationship between psychological contract and job satisfaction,

$\checkmark \quad$ There is also a negative, mid-level and significant relationship between psychological contract and intention to leave,

$\checkmark$ Psychological contract perception of the research assistants strongly and positively affects job satisfaction of them,

$\checkmark$ Additionally, their intention to leave gets less strong, while their perception on the psychological contract at their organization gets more positive.

Consequently, it can be stated that psychological contract in an organisation is an important factor when the workplace peace and turnover rate issues come to terms. Managers and organizations should take care of their behaviours and perceived by their employees in the workplace. Otherwise, these well-educated professionals will begin to search different careers or position in other organizations.

There have been limitations for this research such as sample and repetition. For future studies, the sample of the study can be enlarged by deriving more data from different universities. It will contribute to literature for the compare of previous studies. A greater sampling and deeper analysis are possible for a field study which will need more time as well. In addition, repeated studies may provide comparative information from different periods of time involving conditional changes. 


\section{References}

Appollis, V. P. (2010). The relationship between intention to quit, psychological capital and job satisfaction in the tourism industry in the Western Cape, Doctoral Dissertation, University of the Western Cape.

Argyris, C. (1960). Understanding organizational behavior. London: Tavistock.

Arshad, R. (2016). Psychological contract violation and turnover intention: Do cultural values matter?, Journal of Managerial Psychology, 31(1), 251-264.

Aşan, Ö., \& Erenler, E. (2008). İş tatmini ve yaşam tatmini ilişkisi, Suleyman Demirel University The Journal of Faculty of Economics and Administrative Sciences, 13(2), 203-216.

Aydın, E. (2017). Kültür bağlamında sosyal mübadele: Kuramsal bir çalışma, Uluslararası İktisadi ve İdari Incelemeler Dergisi, (16. UİK Özel Sayıs1), 547-562.

Aykan, E. (2014). Effects of perceived psychological contract breach on turnover intention: Intermediary role of loneliness perception of employees, Procedia - Social and Behavioral Sciences, 150, 413-419.

Bal, P. M., \& Dorien, K. (2011). The relations between work centrality, psychological contracts and job attitudes: The influence of age, European Journal Of Work And Organizational Psychology, 20(4): 497-523

Ballou, N. S. (2013). The effects of psychological contract breach on job outcomes, Master's Theses, San José State University.

Bayrak Kök, S. (2006). İş tatmini ve örgütsel bağlılığın incelenmesine yönelik bir araştırma, Atatürk Üniversitesi İktisadi ve Ídari Bilimler Dergisi, 20(1), 291-317.

Behery, M., Abdallah, S., Parakandi, M., \& Kukunuru, S. (2016). Psychological contracts and intention to leave with mediation effect of organizational commitment and employee satisfaction at times of recession, Review of International Business and Strategy, 26(2), 184-203.

Blau, P. M. (1989). This week's citation classic. Retrieved from

http://www.garfield.library.upenn.edu/classics1989/A19 89CA27000001.pdf, Access Date: 11, 21, 2020, Current Contents, December, 4, 1989.

Blomme, R. J., Van Rheede, A., \& Tromp, D. M. (2010). The use of the psychological contract to explain turnover intentions in the hospitality industry: A research study on the impact of gender on the turnover intentions of highly educated employees. The International Journal of Human Resource Management, 21(1), 144-162.

Cho, S., Johanson, M. M., \& Guchait, P. (2009). Employees intent to leave: a comparison of determinants of intent to leave versus intent to stay. International Journal of Hospitality Management, 28(3), 374-381.

Collins, D. (2010). The effect of psychological contract fulfillment on manager turnover intentions and its role as a mediator in a causal, limited-service restaurant environment, International Journal of Hospitality Management, 29, 736-742.
Conway, N., \& R. B. Briner. (2002). A daily diary study of affective responses to psychological contract breach and exceeded promises, Journal of Organizational Behavior, 23, 287-302.

Conway, N., Guest, D., \& Trenberth, L. (2011). Testing the differential effects of changes in psychological contract breach and fulfillment, Journal of Vocational Behavior, 79(1), 267-276.

Çöp, S., \& Doğanay, A. (2020). Algılanan liderlik iletişiminin iş performansı ve iş tatminine etkisi: 4 ve 5 yıldızlı otel çalışanları üzerine bir araştırma, Istanbul Gelişim Üniversitesi Sosyal Bilimler Dergisi, 7(1), 3449.

Efron, B., \& Tibshirani, R. J. (1993). An introduction to the bootstrap, New York: Chapman and Hall (Springer Science+Business Media).

Gakovic, A., \& Tetrick, L. E. (2003). Psychological contract breach and as a source of strain for employees, Journal of Business and Psychology, 18, 235-246.

Gaur, A. S., \& Gaur, S. S. (2009). statistical methods for practice and research: A guide to data analysis using SPSS (second edition), New Delhi: Response Books.

Gümüş Dönmez, F., \& Topaloğlu, C. (2020). Otel Çalışanlarında Algılanan Örgütsel Destek, İş Yeri Yalnızlığı ve İş Tatmini İlişkisi, İş ve İnsan Dergisi, 7(2), 311-324.

Hemdi, M. A., \& Rahim, A. R. A. (2011). The effect of psychological contract and affective commitment on turnover intentions of hotel managers. International Journal of Business and Social Science, 2(23), 76-88.

Hinton, P. R., Brownlow, C., McMurray, I., \& Cozens, B. (2004). SPSS explained, London: Routledge.

Johnson, J. L., \& O'learry-Kelly, A. M. (2003). The effects of psychological contract on breach and organizational cynicism: Not all social exchange violations are created equal, Journal of Organizational Behavior, 24, 627-647.

Kâhya, C. (2013). Örgütsel sinizm, iş performansını etkiler mi? iş tatminin aracilık etkisi, Global Journal of Economics and Business Studies, 2(3), 34-46.

Kahyaoğlu, M., \& Akca, M. (2020). Kurumsal imajın iş tatminine etkisinde duygusal bağlılığın rolü: Konaklama işletmeleri üzerinde bir araştırma, Turizm Akademik Dergisi, 7(1), 225-240.

Karcıoğlu, F., \& Akbaş, S. (2010). İşyerine psikolojik şiddet ve iş tatmini ilişkisi, Atatürk Üniversitesi İktisadi ve İdari Bilimler Dergisi, 24(3), 139-161.

Kaya, D. (2013). Örgütsel vatandaşlık davranışı. Türk İdare Dergisi, 476, 265-288.

Knights, J. A., \& J. K. Barbara. (2005). Psychological contract violation: Impact on job satisfaction and organizational commitment among Australian senior public servants, Applied Human Resources Management Research, 10(2), 57-72.

Lacity, M. C.; Iyer V. V., \& Rudramuniyaiah, P. S. (2008), Turnover intentions of indian IS professionals. 
Information Systems Frontiers, 10(2), 225-241. http://dx.doi.org/10.1007/s10796-007-9062-3.

Leech, N. L.; Barrett, K. C., \& Morgan, G. A. (2005). SPSS for intermediate statistics: use and interpretation (second edition), New Jersey: Lawrence Erlbaum Associates, Inc., Publishers.

Levinson, H., Price, C. R., Munden, K. J., Mandl, H. J., \& Solley, C. M. (1962). Men, management, and mental health, Cambridge, MA, US: Harvard University Press.

Lu, H., While A. E., \& Barriball K. L. (2005), Job satisfaction among nurses: A literature review, International Journal of Nursing Studies, 42, 211-227.

Malik, S. Z., \& Khalid, N. (2016). Psychological contract breach, work engagement and turnover intention, Pakistan Economic and Social Review, 54(1), 37-54.

Manxhari, M. (2015). Employment relationships and the psychological contract: The case of banking sector in Albania, Procedia-Social and Behavioral Sciences, 210, 231-240.

Matz, A. K., Woo, Y., \& Kim, B. (2014), A meta-analysis of the correlates of turnover intent in criminal justice organizations: Does agency type matter?, Journal of Criminal Justice, 42(3), 233-243. http://dx.doi.org/10.1016/j.jcrimjus.2014.02.004

Örücü, E., Yumuşak, S., \& Bozkır Y. (2006). Bankalarda çalışan personelin iş tatmini ve iş tatminini etkileyen faktörlerin incelenmesine yönelik bir araştırma, Celal Bayar Üniversitesi IIIBF Yönetim ve Ekonomi Dergisi, 13(1), 40-51.

Page, M. C., Braver, S. L., \& MacKinnon, D. P. (2003). Levine's guide to SPSS for analysis of variance (second edition), New Jersey: Lawrence Erlbaum Associates, Inc.

Pallant, J. (2007). SPSS survival manual: A step by step guide to data analysis using SPSS for windows, (third edition), Berkshire: McGraw-Hill Open University Press.

Piko, B. F. (2006), Burnout, role conflict, job satisfaction and psychosocial health among Hungarian health care staff: A questionnaire survey, International Journal of Nursing Studies, 43, 311-318.

Price, J. L. (1989). The impact of turnover on the organisation, Work and Occupations, 16(4), 461-473.

Price, J. L. (2001). Reflections on the determinants of voluntary turnover, International Journal of Manpower, 22(7), pp. http://dx.doi.org/10.1108/EUM0000000006233

Rayton, B. A., \& Yalabik, Z. Y. (2014). Work engagement, psychological contract breach and job satisfaction, The International Journal of Human Resource Management, 25(17), 2382-2400.

Resnick S., \& Bond, G. R. (2001). The Indiana job satisfaction scale: Job satisfaction in vocational rehabilitation for people with severe mental illness, Psychiatric Rehabilitation Journal, 25, 12-19.

Rigotti, T. (2009). Enough is enough? threshold models for the relationship between psychological contract breach and job-related attitudes, European Journal of Work and Organizational Psychology, 18, 442-463.

Robinson, S. L., \& Rousseau, D. M. (1994). violating the psychological contract: Not the exception but the norm, Journal of Organizational Behavior, 15(3), 245-259.

Rosin, H., \& Korabik, K. (1995). organizational experiences and propensity to leave: A multivariate investigation of men and women managers, Journal of Vocational Behavior, 46(1), 1-16.

Rousseau, D. (1995). Psychological contracts in organizations: Understanding written and unwritten agreements, New York: Sage Publications.

Rousseau, D. M. (1989). Psychological and implied contracts in organizations, Employee Responsibilities and Rights Journal, 2, 121-139.

Sökmen, A. (2006). Lider üye etkileşimi, iş tatmini ve örgütsel özdeşleşme ilişkisi: Ankara'daki otel işletmelerinde ampirik bir araştırma, Journal of Tourism and Gastronomy Studies, 8(3), 2132-2143.

Takase, M. (2010). A concept analysis of turnover intention: Implications for nursing management, Collegian, 17, 312.

Turnley, W. H., \& Feldman, D. C. (2000). Re-examining the effects of psychological contracts violations: Unmet expectations and job dissatisfaction as mediators, Journal of Organizational Behavior, 21, 25-42.

Turnley, W. H., Bolino.M. C., S Lester. W., \& Bloodgood, J. M. (2003). The impact of psychological contract fulfillment on the performance of in-role and organizational citizenship behavior. Journal of Management, 29(2), 187-206.

Umar, S., \& Ringim, K. J. (2015, May). Psychological contract and employee turnover intention among Nigerian employees in private organizations. in Management International Conference, 1(1), 219-229.

Van der Vaart, L., Linde, B., \& Cockeran, M. (2013). The state of the psychological contract and employees' intention to leave: The mediating role of employee wellbeing. South African Journal of Psychology, 43(3), 356369.

Van Schalkwyk, S., Du Toit, D.H., Bothma, A.S., \& Rothmann, S. (2010). Job insecurity, leadership empowerment behaviour, employee engagement and intention to leave in a petrochemical laboratory. $S A$ Journal of Human Resource Management/SA Tydskrif vir Menslikehulpbronbestuur, 8(1), 234-240, DOI: 10.4102/sajhrm. v8i1.234

Vandenberg, R.J., \& Nelson, J. B. (1999). Disaggregating the motives underlying turnover intentions: When do intentions predict turnover behaviour?, Human Relations, 52, 1313-1336.

Weiss, D.J., Davis, R.V., England, G.W., \& Lofquist, L.H. (1967) Manual for the Minnesota satisfaction questionnaire. Minneapolis: The University of Minnesota Press. 
Yenihan, B. (2014). Örgütsel bağlılık ve iş tatmini arasındaki ilişki, Karabük Üniversitesi Sosyal Bilimler Enstitüsü Dergisi, 4(2), 170-178.

Yücekaya, P., \& Gümüş, Z. (2020). Örgütsel güvenin iş tatminine etkisinde örgütsel özdeşleşmenin aracı rolü: İmalat sektöründe bir araştırma, International Journal of Tourism, Economic and Business Sciences, 4(2): 44-54.
Yüksel, İ. (2005). İş-aile çatışmasının kariyer tatmini, İş tatmini ve iş davranışları ile ilişkisi, Atatürk Üniversitesi Íktisadi ve Ídari Bilimler Dergisi, 19(2), 301-314.

Zhao, H., Wayne, S. J., Glibkowski B. C., \& Bravo, J. (2007). The impact of psychological contract breach on work-related outcomes: A meta-analysis, Personnel Psychology, $60(3)$ 647-680. http://dx.doi.org/10.1111/j.1744-6570.2007.00087.x 